\title{
Product Attractiveness and Consumers' Attitude Towards Made- In-Nigeria Textiles in South-South Zone of Nigeria.
}

\begin{abstract}
Etim, Glory Sunday Ph. D
Department of Marketing, University of Calabar, P.M.B. 1115 Calabar Nigeria.

Abstract

This research studied Product Attractiveness and Consumers Attitude towards Made-in-Nigeria textiles in SouthSouth Zone of Nigeria. This was motivated by consumers complaints in the course of my transaction in locally made fabrics. The study examined the effect of product attractiveness in terms of design and packaging on consumers' attitude towards made-in-Nigeria textiles. The specific objectives were to; examine the effect of packaging on consumers' Attitude towards Made-in Nigeria Textiles in South-South Zone of Nigeria; determine the effect of design on consumers' Attitude towards Made-in Nigeria Textiles in South-South Zone of Nigeria. A survey design was used in gathering data needed for the research. Copies of questionnaire were self-administered to a sample of four hundred (400) consumers, at the end 358 was retrieved and analysis was done based on the 358. Descriptive statistics was used in the application of percentages and other statistical procedures. Linear regression analysis was used to establish and measure the cause-effect relationship between product design, product packaging and consumers' attitude towards Made in Nigeria Textiles in South-South Zone of Nigeria. The result revealed that there is a significant effect between product packaging and consumers' attitude towards made-in-Nigeria textiles, but the analysis on product design was insignificant. The study therefore recommends that good informative packaging should be done with beautiful and meaningful design to make the products attractive in order to properly position it in the minds of the consumers, this will make them buy made- in- Nigeria textiles thereby boosting the growth/ development of the economy.
\end{abstract}

Keywords: Product Attractiveness, design, packaging, Consumers' Attitude, and Made-In-Nigeria Textiles

DOI: $10.7176 / \mathrm{JMCR} / 54-08$

Publication date:March $31^{\text {st }} 2019$

\subsection{Introduction}

Product attractiveness in terms of packaging and design has been of immense benefits to production companies. It is used to communicate values about almost all types of products ranging from durable, examples clothing, cars, refrigerator, tables, chairs among others and non-durable, examples toothpaste, body cream, soft drinks and so on. Auger, Devinney, Louviere, Burke, (2010) notes that, because of ubiquity of local and international products consumers have the opportunity to become better informed about variety of products. This makes it imperative for companies to improve upon their quality, innovativeness, design, and packaging. In addition, (Rundh, 2005; Underwood, 2003; Silayoi, \& Speece, 2007) explain that design and packaging appeals consumer's attentiveness towards a certain brand, increases its image, and stimulates consumer's perceptions about products, and also conveys distinctive value to products.

Consumer attitude is a useful component in product packaging and design, the reason is because it serves as a propelling force that aid consumers to take purchase decision. Etuk (2010) observe that consumer attitude as predispositions to behave favorably or unfavorably toward persons, situations, ideas, objectives, or the behaviour of others.

Due to variety of similar products, consumers look out for unique products features to enable them make best decisions. To help consumers make inform decision producers must ensure that both the intrinsic and extrinsic features like design, packaging, quality and so on are attractive. Consumers may become fascinated or influenced either negatively or positively by these attributes. Many researchers have keen interest in identifying the possible variables responsible for improving the growth of Nigeria's economy, and this to a large extent makes product attributes substantial in the development of the economy. Schnurr, Brunner-Sperdin, and Stokburger-Sauer, (2016) opine that knowing how design and packaging affects consumers' perceptions of products will certainly help companies display products in a way that makes them appear most attractive. Ordinarily, when a product elicits positive perceptions of attractiveness, consumers are likely to engage in approach behavior, such as spending additional time looking at the product or willingness to buy it (Schnurr et al, 2016). This will result in improving living conditions of the people and gross domestic product of the country. Furthermore, it will encourage 
diversification of the economy and reduction of overdependence on the oil sector for economic growth and survival.

Textile industries have been identified as a dependable employer of labour and a source of financial security for most Nigerian youths (Aremo, 2014) in Makinde, Fajuyigbe and Ajiboye (2015). There are different textile manufacturing companies in Nigeria today with over 60 to 70 percent of its employee as youths, for example, African Textile Manufacturers Limited with headquarters at Kantin Kwari, Kano State Nigeria is a Nigerian textile manufacturing company that offers the printing and sales of Crowntex, Duniya, Queentex, Abada, Real wax and so on, Da Viva Textile is situated at Polo Park, Enugu, that are into the production of traditional African fabrics and textile with new and beautiful designs, Nigeria T-shirt Factory popularly known as NTF is located at isheri north GRA, Lagos State is currently Africa's fastest growing garment manufacturing company in Nigeria, known for making brand t-shirts, polos, and school uniforms. The public orientation towards made-in-Nigeria textile products needs to be examined in order to encourage and properly positioned in the minds of the consumers. When this is done, it will go a long way in improving the growth of the nation's economy. This will bring about increase in production, thereby creating employment opportunities and placing food on the table of Nigerians.

Hence, this study seeks to explain the effect of product packaging and design on consumer attitude towards Made in Nigeria Textiles in the South- South zone of Nigeria.

\subsection{Statement of the problem}

It is essential for every product to be attractive in order to arouse interest and invariably lead to consumer buying behaviour. It has been observed over time that a lot of manufacturers unconsciously neglect and forget to stress on product attractiveness such as design and packaging in the process of product development. Consumers, however take cognizance of these features, that is why in most cases, Nigerian consumers prefers foreign made to locally made textiles. For example, in Nigeria today, we have a lot of locally made textiles being used for occasions such as traditional weddings, naming ceremony, child dedication and so on. Despite these numerous advantages, many Nigerians still prefers foreign made textiles. Agbonifoh (1995) as cited in Ogunnaike (2010) observe that consumers consider locally-produced textile inferior compare to the imported ones. Consumers, especially women prefer to wear foreign made products Asen, Eke and Kalejaye (2011). The preference for foreign products to locally made products is high and has indirectly led to the dwindling of the Nigerian economy and the patronage of locally made textiles. Against these odd developments, how can product packaging and design be used to influence Consumers' Attitude towards Made-In-Nigeria Textiles in South-South Zone of Nigeria?

\subsection{Research objectives}

The overall objective of the study is to determine the effect of product attractiveness on consumers' attitude towards made in Nigeria textiles in South-south zone. Specific objectives include;

1. to examine the effect of packaging on consumers' Attitude towards Made-in Nigeria Textiles in South-South Zone of Nigeria;

2. to determine the effect of design on consumers' Attitude towards Made-in Nigeria Textiles in South-South Zone of Nigeria.

\subsection{Research questions}

1. Does product packaging have any effect on consumers attitude towards made-in-Nigeria textile products?

2. Does product design have any effect on consumers attitude towards made-in-Nigeria textile products?

\subsection{Research hypotheses}

The following null hypotheses were tested

$\mathrm{HO}_{1}$ : There is no significant effect between product packaging and consumer attitude towards made - in- Nigeria textile product.

$\mathrm{HO}_{2}$ : There is no significant effect between product design and consumer attitude towards made-in- Nigeria textile products. 


\subsection{Theoretical framework}

The study was hinged on the Fishbein's model of 1967. The model states that attitude towards an item is equal to the sum of the products of the belief about each attribute of the object, weighted by the evaluation of the importance of each attribute of the object, weighted by the evaluation of the importance of each attribute. This means that, the evaluation of various attribute can offset one another

The theory is relevant to this study because it establishes how consumers consider product attributes when choosing from among the same product with different brands, since there are many attributes that consumers consider during their choice of textile products, such as product design and packaging. This implies that the evaluation of various attributes can offset one another. That is, a consumer may be looking out for either design or packaging in order to make their choices. That is product design can offset packaging. In other words, this theory helps us to understand that consumers do not just decide to buy but look out for certain attributes. Like in the case of textile products, consumers could decide to buy a textile product, if impressed by any of the product attributes and not necessarily all of the attributes. The advantage of the Fishbein model is that it shows which patterns are very important to the consumers in examining attitudes toward the product. Hence, if producers and dealers of textile products take cognizance of Fishbien theory, product attributes will be adequately considered. By so doing, consumers will be captivated by one or more attributes which will in turn spur them to buy.

The criticism against this theory is pointed out to be the ignorance of the connections between individuals, both the interpersonal and social relations in which they act, and the broader social structures which govern social practice.

\subsection{Packaging and Consumers' Attitude towards Made in Nigeria Textile Products}

Different marketing messages are directed at consumers from different textile companies, especially the ones with similar products. Consumers to an extent gets confused about the best alternatives. This makes packaging more significant. Zekiri and Hasani, (2015) is of the opinion that a good packaging should be able to help, identify and differentiate products for the consumers. Consumers respond to packaging based on previous information, learned reactions and individual preferences (Aaker 2010) as cited in (Zekiri et al, 2015). No matter the quality and benefits derived from a product, its price, promotion and delivery effectiveness, if the package is not appealing, it may amount to complete reflection of the total marketing effort (Ebitu, 2012). Packaging involves designing and producing a unique coverage for a product. The manner in which a product is packaged will determine how such product will be promoted. Pilditch (1982) sees packaging as the silent salesman in the store and the only communication between a product and a company's consumer at the point of sales.

Today, packaging of made-in- Nigeria textile products has become an ultimate selling proposition stimulating impulse buying behaviour. Packaging component of a product is any special container offered for sale and on which information is communicated (Kevin, 1983). Thus, it includes all the operations involved in the preparation of products for carriage, storage and delivery (Oyedijo, 1996). In other words, packaging is the act of containing, protecting, and presenting a content through the long chain of production, handling, and transportation to their destination in a good state as it were as at the time of production (Panver, 2004).

The words of (Shimp, 2010) has it that, it is fundamental to underline that a package is the product itself, as it performs key communication and sales roles at the point of purchase since consumers have limited time at their disposal especially where low involvement products are concerned. He explained that, packaging also serves among other things, to draw attention to a brand, break through competitive clutter at the point of purchase, justify price and value to the consumer. The relevance of packaging has been facilitated not only by the need to communicate to customers about the product and its brand but also to influence them in making informed decisions.

Packaging brings such things as reassurance, feelings of status, pleasant associations and so on (Wright, 2006). It involves promoting, protecting and enhancing the product, which can be important to both sellers and customers (Perreault, Cannon \& McCarthy 2008).

Packaging is an important brand element with more tangible or physical benefits than other brand elements (Grewal \& Levy, 2012). Packaging also served practical function, that is, it holds content together and protect goods as they move through the distribution channel. Today, however, packaging is also seen as a container for promoting a product and making it easier and safer to use (Lamb, Hair \& McDaniel, 2006). An additional function of packaging that is becoming increasingly important is the fact that, it facilitate recycling and reduce environmental damage. 
According to Kotler and Armstrong (2013), packaging involves designing and producing the container or wrapper for a product. Companies now realize the power of good packaging to create immediate consumer recognition of a brand. Poorly designed packages can cause headaches for consumers and lost sales for the company, while innovative packaging can give a company an advantage over competitors and boost sales, sometimes even seemingly small packaging improvement can make a big difference. Quartey and Abor, (2011) also point out that poor packaging by some manufacturers or exporters also serve as a barrier to exports at the international level. This indicates that packaging should not have or hold misleading or inaccurate information because it could confuse or make consumers lose interest about such a product. Umeh (2009), opine that packaging extends beyond the wrapper or container covering the product to the after benefits built into the product. It is also regarded as a strategic marketing tool (Onah \& Thomas, 1993) in Umeh (2009). It was added that in many instances, however, the satisfaction to be derived from a product is dependent upon its packaging and consumers are very receptive to both technical and aesthical improvement in package design.

If Nigerian fabrics are well package, detailed information given on use of the fabric, consumers will be interested since clear instructions are provided. Examples are plain and pattern, Daviva fabrics have fantastic packaging.

Over $70 \%$ of purchase decisions are made at the shelf and since packaging of product is the first thing that a consumer sees, it plays a vital role in differentiating a brand from that of a competitor. Ahmad and Billoo (2012) outlined the following as some of the benefits business stand to gain when they improve upon their packaging;

$>$ Perceptible representation of company brand values.

$>$ Substantial enhancement of product delivery and experience.

$>$ Increased impression at point of purchase

$>$ New opportunities

\subsection{Design and Consumers' Attitude towards Made-In-Nigeria Textiles Products}

Competing favorably in the market place and having loyal customers means that companies must come up with products with good designs. The textiles industry is one with stiff competitions where different similar products are produce. Since products design is a non-verbal method for communicating thoughts and genuity of an item, producers ensure quality product design in order to compete favorably in the market place. Ding-Bang (2015) observed that to win from the onset, it is necessary to include customer loyalty skills into the design repertoire. That is, product designers should take customer loyalty factors into account as an important design element, function and goal.

Kotler \& Armstrong, (2013) defined design as a way of adding value to customers through distinctive product design. Thus, it describes the process of designing a product styles and function, creating a product that is attractive, easy, safe and inexpensive to use. In other words, good designs contribute to a product's usefulness as well as it looks.

Great design adds to the beauty of any product, and also helpful in the overall idea behind the product concept. Pye 1978 as cited in (Horvath, 2001) outline some basic requirements for a good product design in order to achieve a particular result. They include the followings;

$>$ It must appropriately represent the vital principle of preparation.

$>$ The mechanisms of the device/ product must be geometrically related.

$>$ Access must be provided.

$>$ The fee of the result must be acceptable for economy consumption

$>$ The appearance of device/ product must be acceptable.

Fashion design is a matter of mixing elements in new and existing ways in order to create fresh combination and products (Jones, 2005). Design comes in different shapes and sizes. Production companies should be able to tell when to use appropriate design line for a particular purpose and target audience in order to achieve desired response from consumers. Kotler and Keller (2007) points out that horizontal line represent restlessness, vertical lines evoke strength, confidence and pride, slated lines represent upward movement. The main design elements are either twodimensional shape, three-dimension silhouette, constructing line graphics color, texture and so on. Product design that is developed for a specific market or for some defined consumer is called customer-oriented product design. The objectives of customer-oriented product designs are to find real customers' needs, satisfy customers and solve 
current problem via possible various approaches. $\mathrm{Ng}$ and Wang (2007) argue that, some design criteria relative to customer orientation can be set up to assess the result afterwards. In what they referred to as mode, it clearly stated that, all relative or important elements, such as customer needs, product ideas, technological capabilities and design characteristics, should be included for an integrated development.

$\mathrm{Ng}$ and Wang (2007) were of the opinion that many design researchers tend to develop diverse technologies or speculate on new technology in order to explore new approaches to create novelties. This approach is formally referred to as technology development product design. The technology development product design can be part of customer-oriented product development. $\mathrm{Ng}(1998 ; 2001)$ in Wang and $\mathrm{Ng}$ (2007) lay emphasis on design projects, which they explain to be as example of technology deployment product design.

\section{Types of Product design}

Product designs can be view from different perspectives, depending on the individual manufacturer or company. Gilal, Zhang, and Gilal, (2018), listed types of design to be;

$>$ Aesthetic design- it refers to the physical appearance or the beauty of a product.

$>$ Functional product design- it is the basic functionality of a product or what a product is to be used for.

$>$ Symbolic design- it focuses on the specific meanings or signs that communicate status, or self-image on the basis of visual elements.

Hence, as rivalry strengthens, design will have to offer a high standard and also be unique in order to differentiate each company products, because this is the strongest instruments for distinguishing an organizational product (Kotler \& Armstrong, 2013).

\subsection{Methodology}

The study adopted survey design in which data was collected through structured questionnaire. It was undertaken in Cross River, Akwa Ibom, Rivers, Bayelsa, Delta, and Edo States in the South-South zone of Nigeria, with a total population of 21,014,655 (Federal Republic of Nigeria Official Gazette, 2007). The Taro Yamane formula for known population was adopted to determine the sample size, which amounted to 400. After which questionnaire was distributed using the simple random sampling to select three states from the six states using the ballot system. The stratified sampling technique was applied by way of accruing percentage to the three selected states representing the south-south zone. This was done by substituting the total population of the three states and multiplying by 100 .

By sharing the sample size of 400 among the three states representing the zone based on percentages accruing to each, we had the followings;

Cross River $=\underline{26.5} \times \underline{400}=106$

$100 \quad 1$

Akwa Ibom $=\underline{35.9} \times \underline{400}=143.6=144$

1001

Delta State $=\underline{37} \times \underline{400}=150$

$100 \quad 1$

Out of the 400 copies of questionnaire administered by the researcher, 358 were retrieved and analysis was done based on it. The questionnaire consisted of items with opened ended, closed-ended style of statements based on the Likert scale ranging from: Strongly Agree (5), Agree (4), Undecided (3), Disagree (2), Strongly Disagree (1). At the end analysis was done using the linear regression analytical tool on Spss version 21

\section{Reliability of the instrument}

The test-retest was conducted to check the consistency of the measuring tool. This was done by administering 20 copies of questionnaire to 20 youth and adults in Calabar. The results so obtained yielded Cronbach's Reliability Alpha of 0.72 and above for each of the variables, implying that the instrument had a strong internal reliability. 
The following table shows the Cronbach Alpha Reliability Co-efficient for each of the variables.

Table 1.1 Cronbach's Alpha Coefficient reliability estimate

\begin{tabular}{|c|c|c|c|c|c|c|}
\hline $\mathrm{S} / \mathrm{n}$ & Variables & No of respondents & $\begin{array}{c}\text { No } \\
\text { items }\end{array}$ & Mean & $\begin{array}{l}\text { Standard } \\
\text { deviation }\end{array}$ & Reliability \\
\hline 1. & $\begin{array}{l}\text { Consumer } \\
\text { Attitude }\end{array}$ & 20 & 4 & 8.73 & 2.95 & 0.74 \\
\hline 2. & Packaging & 20 & 4 & 8.57 & 3.41 & 0.82 \\
\hline 3. & Design & 20 & 4 & 8.70 & 2.79 & 0.73 \\
\hline
\end{tabular}

\subsection{Data Presentation, Analysis and Discussion of Findings}

\section{Hypothesis one}

$\mathrm{H}_{1}$ : There is no significant effect between product packaging and consumer attitude towards Made - in- Nigeria textile product.

Linear regression showing the effect of product packaging on Consumer Attitude towards Made - in Nigeria textile

Table 1.2 Model Summary

\begin{tabular}{|l|r|r|r|r|}
\hline Model & \multicolumn{1}{|c|}{$\mathrm{R}$} & R Square & \multicolumn{1}{|c|}{$\begin{array}{c}\text { Adjusted R } \\
\text { Square }\end{array}$} & $\begin{array}{c}\text { Std. Error of the } \\
\text { Estimate }\end{array}$ \\
\hline 1 & $.451^{\mathrm{a}}$ & .322 & .216 & .443 \\
\hline
\end{tabular}

a. Predictors: (Constant), product packaging

Table 1.3

\section{Anova}

\begin{tabular}{|rr|r|r|r|r|r|}
\hline \multicolumn{2}{|l|}{ Model } & Sum of Squares & Df & Mean Square & \multicolumn{1}{|c|}{ F } & \multicolumn{1}{c|}{ Sig. } \\
\hline & Regression & 644.8295 & 1 & 644.8295 & 51.807 & $.000^{\mathrm{b}}$ \\
1 & Residual & 728.1425 & 356 & 6.201 & & \\
& Total & 1372.972 & 357 & & & \\
\hline
\end{tabular}

a. Dependent Variable: Consumer Attitude

b. Predictors: (Constant), Product packaging 
Table 1.4

\section{Coefficients}

\begin{tabular}{|c|c|c|c|c|c|}
\hline \multirow[t]{2}{*}{ Model } & \multicolumn{2}{|c|}{ Unstandardized Coefficients } & \multirow{2}{*}{$\begin{array}{c}\text { Standardized } \\
\text { Coefficients }\end{array}$} & \multirow[t]{2}{*}{$\mathrm{t}$} & \multirow[t]{2}{*}{ Sig. } \\
\hline & B & Std. Error & & & \\
\hline (Constant) & 1.518 & 1.031 & & 1.473 & .142 \\
\hline Packaging & .337 & .070 & .216 & .4 .826 & .000 \\
\hline
\end{tabular}

a. Dependent variable: Consumer Attitude

\section{Hypothesis two}

$\mathrm{HO}_{2}$ : There is no significant effect between product design and consumer attitude towards made -in- Nigeria textile products.

Linear regression showing the effect of product design on Consumer Attitude towards Made - in - Nigeria textile products

Table 1.5

Model Summary

\begin{tabular}{|l|r|r|r|r|}
\hline Model & \multicolumn{1}{|c|}{$\mathrm{R}$} & R Square & \multicolumn{1}{|c|}{$\begin{array}{c}\text { Adjusted R } \\
\text { Square }\end{array}$} & $\begin{array}{l}\text { Std. Error of the } \\
\text { Estimate }\end{array}$ \\
\hline 1 & $.168^{\mathrm{a}}$ & .271 & .168 & 3.149 \\
\hline
\end{tabular}

a. Predictors: (Constant), textile design

Table 1.6

Anova

\begin{tabular}{|rr|r|r|r|r|r|}
\hline \multicolumn{1}{|l|}{ Model } & Sum of Squares & Df & Mean Square & F & Sig. \\
\hline & Regression & 15.090 & 1 & 15.090 & 51.807 & $.056^{\mathrm{b}}$ \\
& Residual & 60.159 & 356 & .201 & & \\
& Total & 75.249 & 357 & & & \\
\hline
\end{tabular}

a. Dependent Variable: Consumer Attitude, b. Predictors: (Constant), Textile design 
Table 1.7

\section{Coefficients}

\begin{tabular}{|c|c|c|c|c|c|}
\hline \multirow[t]{2}{*}{ Model } & \multicolumn{2}{|c|}{ Unstandardized Coefficients } & \multirow{2}{*}{$\begin{array}{c}\begin{array}{c}\text { Standardized } \\
\text { Coefficients }\end{array} \\
\text { Beta }\end{array}$} & \multirow[t]{2}{*}{$\mathrm{T}$} & \multirow[t]{2}{*}{ Sig. } \\
\hline & B & Std. Error & & & \\
\hline (Constant) & 1.518 & 1.031 & & 1.473 & .142 \\
\hline $\begin{array}{l}\text { Textile } \\
\text { Design }\end{array}$ & .051 & .047 & .051 & 1.085 & .279 \\
\hline
\end{tabular}

a. Dependent variable: Consumer Attitude

\section{Interpretation of Result}

Table 1.2, 1.3, and 1.4 report the Linear regression analysis of hypothesis one. The result show that there is a significant effect product packaging on Consumer Attitude towards Made-in-Nigeria textile where $\left(\mathrm{B}_{1}=.561, \mathrm{p}<\right.$ 0.05). Table 1.3 and 1.4 further report a significant $F$ statistic indicating the model prediction strength $\left(\mathrm{R}^{2}=47\right.$ percent, $\mathrm{P}<0.05$ ). The $\mathrm{R}^{2}$ of 45 percent implies that for every unit of change in consumer attitudes towards Madein- in Nigeria textiles, 47 percent of such variation is explained by product packaging on Consumer attitude towards Nigerian textile. Table 1.5, 1.6, and 1.7 also report a Linear regression analysis of hypothesis two. The result showed that textile design makes an insignificant contribution to the model where $\left(\mathrm{B}^{1}=0.051, \mathrm{P}>0.05\right)$, this is because it recorded a least Beta compare to packaging.

\section{Discussion of Findings}

Hypothesis one revealed that packaging has a significant relationship with consumer attitude towards made-inNigeria textile products. This indicates that consumer look out for well packaged textiles. This result is in consonance with that of (Zekiri and Hasani, 2015) who observed that the material used in packaging is an important element which prevents the product from any damage or loss. That, it is more likely that high quality packaged material attract customer more than low quality material. The words of (Pilditch, 1982) has it that packaging is the quiet seller in the shop and the only message between a product and the firm consumers at the points of sale. Umeh (2009) opine that packaging extends beyond the wrapper or container covering the product to the after benefits built into the product. Raheem, Vishnu, and Ahmed (2014) ascertain that packaging is a whole package that becomes an ultimate selling proposition, which stimulates impulse buying behavior. This means that a consumer expects sufficient information about made-in-Nigeria textile products and should be packaged in a way that it does not change state from the way it was produced. Dealers and manufacturers must take note of this if they want to grow and compete favorably. Raheem et al (2014) adds that for any textile company to remain relevance in the industry, attention must be drawn towards packaging material for it is a more important factor when consumers are making any buying decision.

Hypothesis two revealed that there is no significant relationship between design perception and consumers' attitude towards made-in-Nigeria textile products. The result showed that design perception makes an insignificant contribution to the model because of its level of Beta. This means that in as much as textile design is necessary its effect is not really important compare to other product attributes, based on the response gotten from respondents. This implies that made-in- Nigeria textile dealers and manufacturers should be keen and particular about attributes of consumers interest. This is supported by (Kotler and Keller, 2007) who opine that good designs begin with a deep understanding of customer needs more than simply creating product or services attribute, it involves shaping the customers product- use experience. Jones (2005) supported that design is a matter of mixing elements in new and existing ways in order to create fresh combination of ideas and needs, then transforming these ideas to a product through adequate technical characterization and production processes. It is also indicated that dealers and manufacturers of made- in- Nigeria textile products need to focus on the attributes of consumers interest and should be able to translate these ideas into or Nigerian fabrics for consumers to appreciate.

\subsection{Conclusion}

Product attractiveness is significant in for every textile producing company. This attractiveness, which can be inform of packaging, design and so on must be emphasized upon in the production process in order to encourage 
consumers to imbibe the habit of buying made-in-Nigeria textile products. This way, funds remains in Nigeria and invariably adds to economic growth. Hence, since packaging and design perception are highly appreciated by consumers, an understanding should conceivably help the domestic manufacturers to improve upon these areas in which consumers are highly influenced. The will result in increased profit and improved economy.

\subsection{Recommendations}

Textile companies should ensure that Packaging of made-in-Nigeria textile products should be more informative and portable for easy carriage. Beautiful and meaningful designs should be used as this would attract and encourage good patronage.

\section{References}

Ahmad, N., Billoo, M., (2012) Effect of product packaging in consumer buying decisions. Journal of Business Strategies. 6(2), 1-10.

Auger, P., Devinney, T.M., Louviere, J.J., Burke, P.F (2010). The importance of social product attributes in consumer purchasing decisions: A multi-country comparative study. Australia: Melbourne Business School. Retrieved from: https://opus.lib.uts.edu.au/bitstream/10453/14020/1/2008007994.pdf

Ding-Bang, L., (2015). A Preliminary Research on product design strategies for managing customer loyalty. Retrieved from: https://pdfs.semanticscholar.org/4ebc/96b960cc1943717e9de3bef208a5bf1576e4.pdf

Ebitu, E. T. (2012). Marketing communications: Integrated approach. Calabar: University of Calabar Press.

Esu, B.B. (2012). Introduction to marketing. Calabar: Jochrisam Publishers.

Etuk, E.J. (2010). The Nigerian business environment. Calabar: University of Calabar Press.

Gilal, G.N., Zhang, J., \& Gilal, F.G., (2018). Linking product design to consumer behavior: the moderating role of consumption experience. Journal of Psychology Research and Behavioural Management.169-185. Retrieved from: https://www.dovepress.com/terms. Doi.org/10.2147/PRBM.S161384

Hovarth, D. (2001). The role of product design in product related consumer judgements. (Ph.D. Dissertation). Available from: Budapest University of Economic Sciences and Public Administration, Department of Marketing.

Jones, S. J. (2005). Product development and management. Enugu: J.T.C. Publishers

Kashim, I. B., Adigi, B. E. \& Oladumiye, E. B. (2012). The impact of cottage textile on students of textile design in tertiary institutions in south western Nigeria. Education Research Journal. 2(3), 75-86.

Kevin, G. B. (1983). Marketing. Plymouth: MacDonald and Evance Ltd.

Khalifa, T. F. (2013). Technical textile, design and methodology. International Design Journal, 3(1), 57-61.

Kotler, P. \& Armstrong, G. (2013). Principles of marketing. New Delhi: Prentice Hall.

Kotler, P. \& Keller, K. L. (2007). Marketing management. New Delhi: Pearson Educational Inc.

Lamb, Jr. C. W., Hair, Jr. J. F. \& McDaniel, C. (2006) Marketing London: Thomson SouthWestern.

Makinde, D. O., Fajuyigbe, M. O. \& Ajiboye, O. J. (2015). Nigerian textile industry: A tool for actualizing economic stability and national development. European Journal of Business and Social Sciences, 4(8), 331-344.

National Population Commission (2007). Federal Republic of Nigeria official gazette.

Nigeria Textile Manufacturing Industries, (2018). Retrieved from: https://www.finelib.com/business/manufacturing-industries/textile-manufacturing

NG, M. C. F \& Wang, X (2007). Collaborative Decision-making: Design process toward integrated product Design. International Association of Societies of Design Research, 7(5), 1-15.

Ogunnaike, O. (2010). Nigerian's perception of locally made products: A study on textile fabrics consumers in Kaduna State. Petroleum Gas University of Plastic Bulletin, 
62(1), 30-36.

Oyedijo, A. (1996). Fundamentals of marketing. Ibadan: Paramount Book Ltd.

Panvar, J. S. (2004). Beyond consumer marketing: Sectoral marketing and emerging trends, New Delhi: Tejeshwar Singh Forresponse Books.

Perreault, Jr. W.D., Cannon, J.P., \& McCarthy, E.J. (2008). Basic marketing, a marketing strategy planning approach. Mexico City: McGraw-Hill.

Pilditch, J. (1982). The silent salesman. New Jersey: Random House Business Books.

Quartey, P. \& Abor, J. (2011). Do Ghanaians prefer imported Textiles to locally manufactured ones? Doi: 10.423/me.2011. 21009. Published online February 2011.

Raheem, A.R., Vishnu, P., \& Ahmed, A.M., (2014). Impact of product packaging on consumer buying behaviour. European Journal of Scientific Research.122(2). DOI: 10.13140/2.1.2343.4885

Schnurr, B., Brunner-Sperdin, A. \& Stokburger-Sauer, N.E., (2016). The effect of context attractiveness on product attractiveness and product quality: the moderating role of product familiarity. Springerlink.com. DOI 10.1007/s11002-016-9404-3

Shimp, J. A. (2010). Advertising promotion and other aspects of integrated marketing communication. New York: South Western Cengage Learning.

Umeh, C. I. (2009). Influence of packaging on consumer purchase decision. Journal of Business and Finance. 2(1), 150-159.

Wright, R. (2006). Consumer behaviour. London: Thomson Learning

Zekiri, J., \& Hasani, V.V., (2015). The role and impact of the packaging effect on consumer buying behaviour. Ecoforum. (4)1 